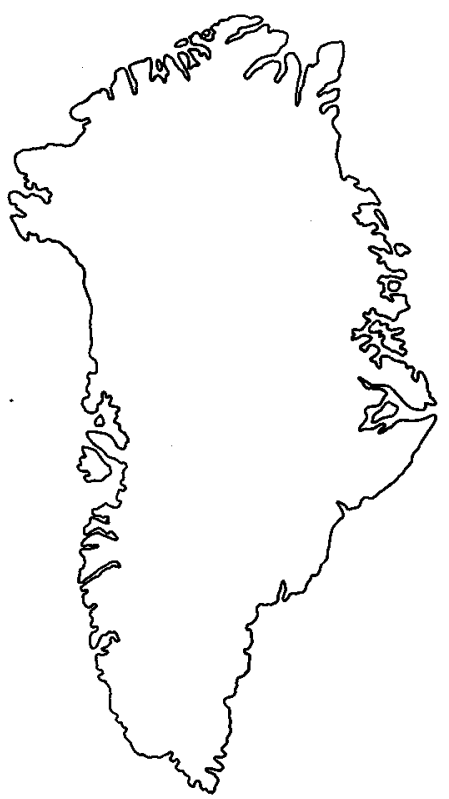

\title{
Operation Grant Land 1965- 1966; a geological exploration programme in Ellesmere Island and North Greenland
}

\author{
Peter R. Dawes
}

This paper summarises field activities carried out in Greenland under the Canadian-Danish geological programme, Operation Grant Land, 1965-1966. The historical background and aims of Operation Grant Land are described and a short history of the geological exploration carried out in western North Greenland is given.

P. R. D., Grønlands Geologiske Unders $\emptyset$ gelse, $\emptyset$ ster Voldgade 10, DK-1350 København K, Danmark.

Operation Grant Land was the first cooperative field venture between the Geological Survey of Canada (GSC) and the Geological Survey of Greenland (GGU) aimed at relating the structural and stratigraphic features across Nares Strait - the narrow seaway separating north-western Greenland from the Canadian Arctic Islands. Studies under Operation Grant Land were among the last activities in the reconnaissance phase of geological field work in this part of western North Greenland. Modern systematic mapping and regional investigations were initiated by GGU during 1984.

\section{Historical background}

The geology of continental margins received renewed interest in the early $1960 \mathrm{~s}$ when the concept of continental drift was rejuvenated by the advent of the theory of sea-floor spreading. Thus Nares Strait, portrayed as a great displacement line in the theories of Frank Taylor and Alfred Wegener, came into focus again as the possible site of a fundamental rift along which Greenland had separated from the Canadian Arctic Archipelago. Speculations arose that a branch of the Mid-Atlantic Ridge lay under Nares Strait and connected the oceanic areas of Baffin Bay and the Arctic Ocean (fig. 1).

Ideas on Nares Strait geotectonics culminated with the work of Tuzo Wilson who suggested that a major transcurrent-transform fault, the Wegener Fault, occupied the Strait (Wilson, 1963a, 1963b, 1965). He directed attention to the steep cliffs of Robeson Channel in northern Nares Strait and suggested that the cliffs were evidence of faulting and that a prominent onshore fault lineament on Judge Daly Promontory is a segment of the Wegener Fault (fig. 2). At the time of Wilson's revolutionary ideas, only occasional field parties had 


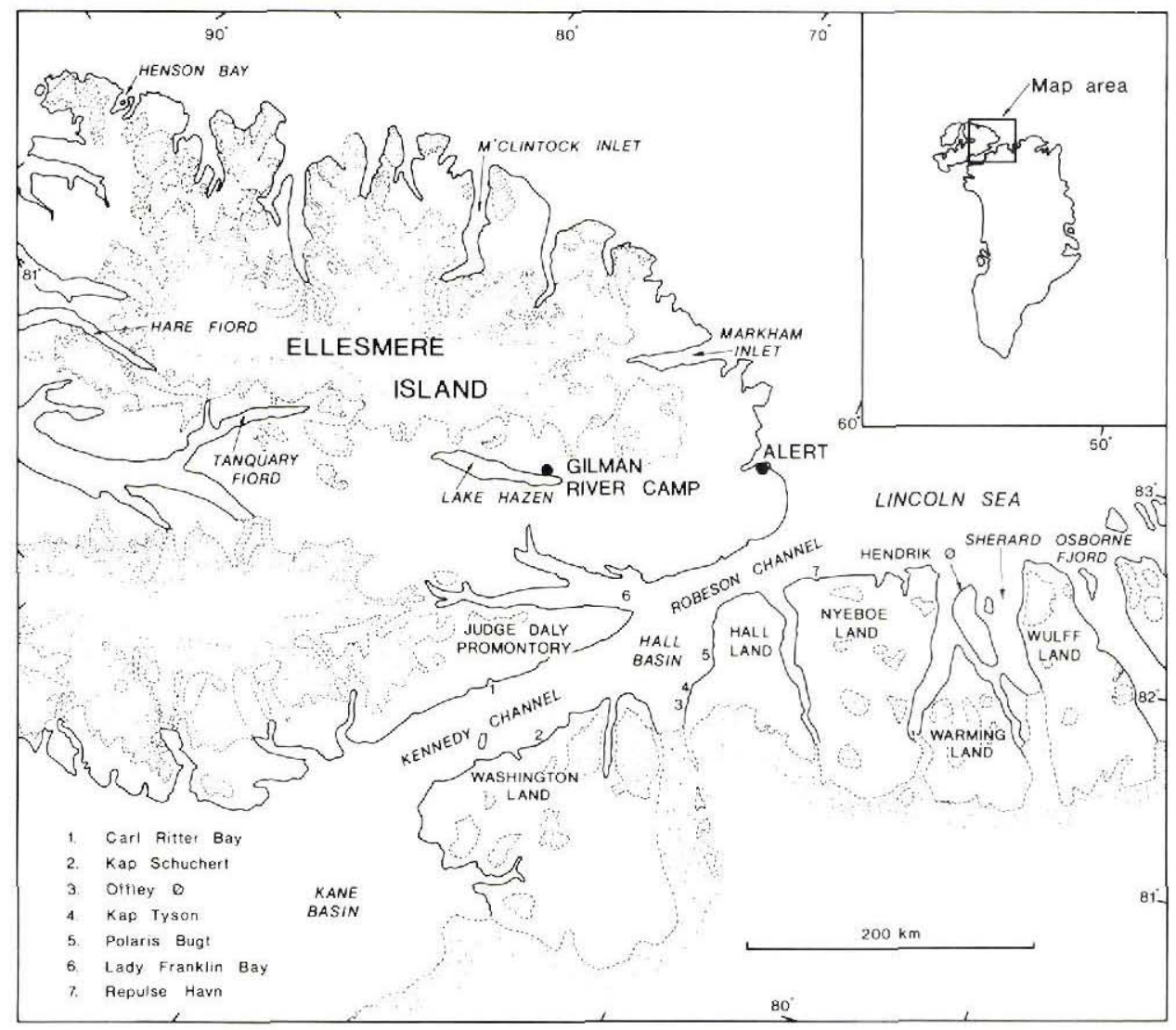

Fig. 1. Location map of the northern Nares Strait region. The area studied under Operation Grant Land is mainly north of the $81^{\circ} \mathrm{N}$ parallel stretching from Henson Bay and Hare Fiord in the west to about longitude $50^{\circ} \mathrm{W}$ in Greenland. Base camp localities at Alert and Gilman River are shown.

visited parts of the Canadian side of the Kennedy and Robeson Channels and the Greenland side had remained essentially unvisited since the work of Lauge Koch in the 1920s.

As a response to the great interest generated in Canada in the Wegener Fault, the Canadian government's Department of Mines and Technical Surveys (now Department of Energy, Mines and Resources) began the planning of an extensive earth science research programme in the Nares Strait region which included geodetic, hydrological, geophysical (seismic, magnetic, gravitational) and geological investigations. It was reasoned that if Nares Strait was indeed the expression of a transform fault joining the active spreading centres of the North Atlantic and Arctic Oceans, it should be possible to measure and monitor the present-day movement of the land masses by accurate measurement. Hence, an important part of the planned work was the establishment of geodetic stations on opposite sides of the Strait. In this respect, the Robeson Channel became a key region as the northernmost and narrowest part of the seaway, less than $25 \mathrm{~km}$ wide. The other planned field activities were also intended to span Nares Strait and invitations were extended to several Danish scientific 
Fig. 2. The Robeson Channel dividing Ellesmere Island (EL) and Greenland (background). The straight, steepcliffed coasts suggest fault control. This is the Wegener Fault of Wilson (1963a, 1963b). HL = Hall Land, NL = Nyeboe Land. Photograph by courtesy of the National Air Photo Library, Canada.

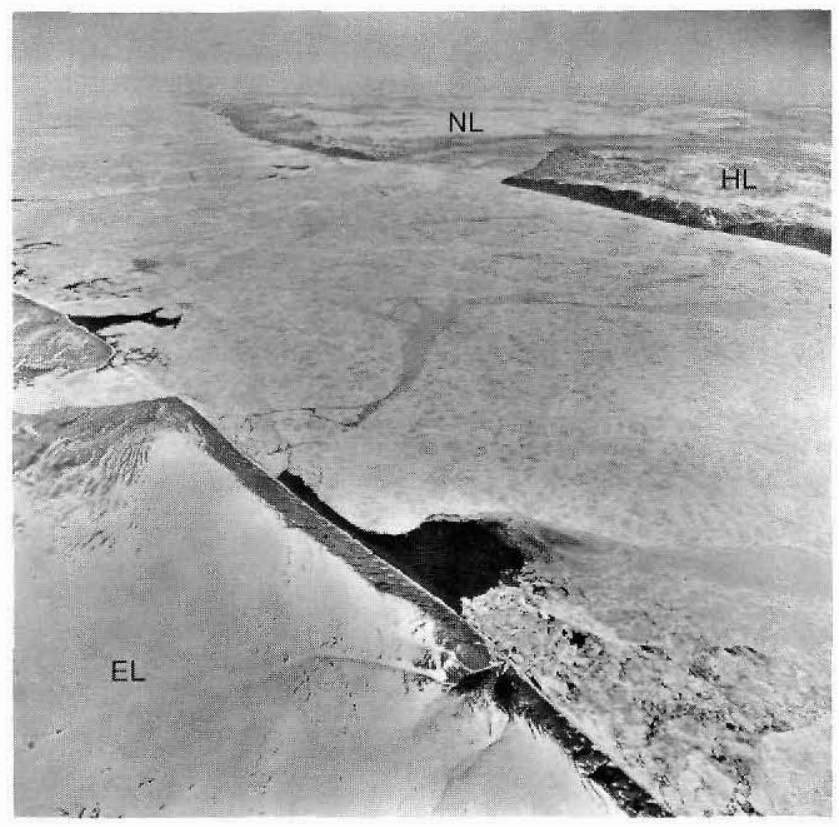

organisations, including GGU, to participate in the programme. A number of the field activities thus came to be organised as joint Canadian-Danish ventures, and one of these, the study of onshore geology, was designated Operation Grant Land.

\section{Aims, field work and results}

Operation Grant Land was organised and led by R. L. Christie of the Geological Survey of Canada as an air-supported, two-summer 'reconnaissance stratigraphic investigation' of northern Ellesmere Island and adjacent northern Greenland (fig. 1). It formed part of a cooperative programme between GSC and GGU to relate structural and stratigraphic features across Nares Strait (Christie, 1966, 1967). The objective of the 1965 season was to obtain geological data in key areas and this was to be followed by further study and formational mapping in 1966. It was expected that the bedrock investigations on either side of the Robeson Channel would allow evaluation of any movement that may have occurred between Ellesmere Island and Greenland along the Wegener Fault.

The field work was concentrated in Ellesmere Island where four GSC teams assigned to the different geological provinces operated each year; one GGU team worked in Greenland each season. Working in the Hall Land area of Greenland in 1965, J. H. Allaart and P. R. Dawes studied both the highly deformed fold belt terrain bordering the Robeson Channel and the homoclinal platform carbonates to the south (Allaart, 1965, 1966). Dawes and Christie also examined the folded Lower Palaeozoic sequence at Carl Ritter Bay on the coast of Ellesmere Island and in the vicinity of Alert. Accompanied by Steen Skytte in 1966, Dawes continued the reconnaissance into Nyeboe Land and Hendrik $\varnothing$, making a cursory examination of northern Wulff Land and the islands in Sherard Osborne Fjord (Dawes, 
1966, 1967). Air reconnaissance of and correlation with the region to the east were made by Dawes and Christie during an extended Beaver flight carried out with one landing in southern Peary Land.

In addition, B. S. Norford (GSC) spent several days in coastal Hall Land (Kap Tyson) and Washington Land (Kap Schuchert) working on the type sections of the established Silurian formations of Koch (1929a) (Norford, 1967, 1972). Jackson \& Etherington (1969) and McLean (1977) have described the graptolites and rugose corals, respectively, from these two localities.

Most of the GGU field work in 1965-66 was concentrated on the highly tectonised Cambrian to Silurian strata of the north coast region and only five fly camps out of a total of 16 were situated on the tectonically simple Ordovician-Silurian sequences of the southern platform. The results of the field work have not been published in full. Some stratigraphic and structual information and small-scale maps have been included in several regional geology accounts (e.g. Dawes, 1971, 1976), and results from the northern part of the study region, bordering the Robeson Channel and Lincoln Sea, were presented in the description of the Nyeboe Land fault zone as a contribution to the Nares Strait geotectonic debate (Dawes, 1982). On conclusion of the field work, the stratigraphic data from the study region were used by Kerr (1967), Geological Survey of Canada, in the assessment of the relationship between Ellesmere Island and Greenland in his definition of the Nares Strait submarine rift. Notes on the stratigraphic sections from which fossils were collected are presented in the following paper of this report.

The Greenland fossil collection as an entity was examined by V. Poulsen, and later by J. S. Peel. Specific fossil groups were studied as follows: graptolites, W. B. N. Berry; brachiopods, A. J. Boucot; pentamerid brachiopods, J. M. Hurst and P. M. Sheehan; conodonts, R. J. Aldridge and H. A. Armstrong; vertebrates, S. E. Bendix-Almgreen and S. Turner; rugose corals, B. E. Neuman; and Silurian trilobites, P. D. Lane. Lane's account of the Silurian trilobites forms part of this report. Certain faunas have been dealt with by Poulsen (1969), Berry et al. (1974), Bendix-Almgreen \& Peel (1974), Bendix-Almgreen (1976) and Peel $(1974,1975,1979)$, while a summation of the fossil identifications was presented by Dawes (1976).

The field work in Greenland was carried out in a reconnaissance mapping style and was not specifically directed to a map compilation at a given scale. The only available base maps, the U.S. Army Map Service series C501 at a 1:250 000 scale based on trimetrogon aerial photographs, were inadequate. Furthermore, in 1965-66 substantial gaps existed in the vertical aerial photographic coverage of the region, including the central part of Nyeboe Land and much of Hall Land. When complete photographic coverage became available in the early 1970s (scale c. 1:54 000, Greenarctic Consortium, Canada), a photogrammetric programme was initiated between GGU and the Institute of Surveying and Photogrammetry, Technical University of Denmark, aimed at the production of a topographical-geological map of Hall Land using advanced, computer-supported techniques (Dawes, 1977, 1979; Dueholm, 1979). The result of this programme, a coloured geological map in two sheets at a scale of 1:66500, is due to be published by GGU in 1985 .

The biostratigraphic and faunal descriptions presented in the papers that follow this account are intended as final reports of the Greenland part of Operation Grant Land. 


\section{Location, physiography and logistics}

The Hall Land - Wulff Land region lies between latitudes $81^{\circ}$ and $82^{\circ} 30^{\prime} \mathrm{N}$ on the north coast of Greenland (fig. 1). The region is ice-bound throughout the year, and in the summer only ice-strengthened vessels can penetrate as far north as Hall Basin with any degree of safety. During the summer, areas of open water may occur in the Hall Basin and Robeson Channel, and also along the coast of Nyeboe Land, but not with sufficient regularity to allow field work by boat.

The physiography of the region has been described by Davies et al. (1959), Ahnert (1962) and Davies (1972). The three main physiographic provinces of the region reflect the contrasting geological terrains and their east-west trends. A southern highland plateau with ice-caps, about $1000 \mathrm{~m}$ elevation, is composed of homoclinal carbonate strata and dissected by steep-sided valleys and canyons. A few summits rise over $1000 \mathrm{~m}$ in a northern mountain chain that consists of an undulating upland of folded and faulted, mainly clastic rocks. A central lowland, etched out of weakly deformed Silurian shaly clastics, is characterised by a thick cover of Quaternary deposits. The region is dissected by a number of north-south trending fjords and valleys that provide well-exposed sections across the approximately eastwest regional strike.

Field work each summer took place between late June and early August and was organised from base camps in Ellesmere Island. In 1965, the base camp was at Alert, $65 \mathrm{~km}$ from the Greenland coast, and the work was supported by a Piper Super Cub and for part of the season by a Hiller 12-E helicopter. At the end of the summer, a Beechcraft 18 aircraft was used to take a series of coloured photographs of fjord and valley walls in Hall and Nyeboe Lands. In 1966, the base camp was moved to Gilman River at the northern end of Lake Hazen (fig. 1) and air support was by De Havilland Beaver, Piper Super Cub and Bell G-4 helicopter.

The Beaver and Cub aircraft from Bradley Air Services were equipped with very low pressure, oversize balloon tyres, enabling landings on rough, unprepared ground; fly camps in Greenland were mainly established by these aircraft (fig. 3). Each field season amounted to about 30 working days; traverses were on foot with occasional air reconnaissance during camp moves.

\section{Early expeditions and geological work}

Nares Strait was an important route for expeditions struggling for the North Pole during the 1800 s and early 1900 s, but the early visitors were more concerned with geographical discovery than with the then young science of geology. The North Polar Expedition, 187173 , led by C. F. Hall in the USS Polaris was the first expedition to negotiate the Robeson Channel. The Polaris reached as far north as Repulse Havn in north-western Nyeboe Land at $82^{\circ} \mathrm{N}$ before finding a wintering site in Polaris Bugt off the western coast of Hall Land. The expedition discovered that the region is composed of two geological terrains: a northern folded unit of dark coloured slates, sandstones, slaty limestones and 'argillaceous schists', and a southern homoclinal to flat-lying unit of light coloured fossiliferous limestones (Davis, 1876; Bessels, 1879). Fossils, including corals, cephalopods and brachiopods, were collected mainly from Offley $\varnothing$, and Bessels (1879) correctly identified the age of the strata of that area as Silurian. 


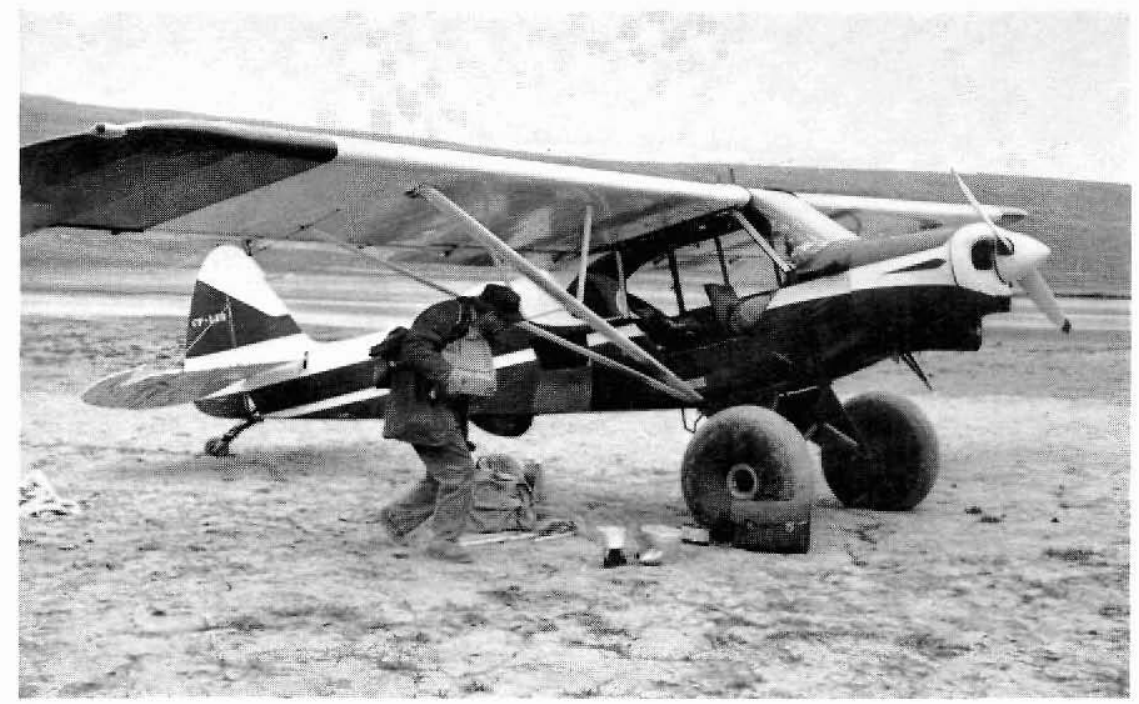

Fig. 3. Piper Super Cub aircraft, equipped with oversize tyres, used for establishing fly camps in Greenland during Operation Grant Land.

Sledge parties from the Royal Navy Arctic Expedition, 1875-76, under G. S. Nares in HMS Alert and HMS Discovery, reached the Greenland coast from winter quarters in Ellesmere Island. The folded rocks of the outer coast were described and traced eastwards as far as western Wulff Land. These rocks were correctly correlated with the clastic strata on the Ellesmere side of the Robeson Channel and designated the Cape Rawson Beds, although the age was inferred to be 'Huronian' (Feilden \& De Rance, 1878). Important results were the first geological map of the region (fig. 4) and the first systematic description of Ordovician-Silurian fossils from Greenland (Etheridge, 1878).

The U.S. Lady Franklin Bay Expedition, 1881-84, led by A. W. Greely, wintered on the Ellesmere side of Hall Basin. Sledge parties reached Hall Land and the coast to the east. Apparently, few geological observations were recorded from the study region and nothing new was added to the geological map (Dawson, 1887, fig. 4). A notable discovery by D. L. Brainard was the occurrence of fossiliferous rocks in north-western Nyeboe Land (Greely, 1886, vol. 1, p. 346; glacial erratics? Koch, 1920, p. 33); this may be the earliest record of in situ fossiliferous strata in the North Greenland fold belt. Most of the collections were abandoned during the tragic retreat of the expedition in 1884 .

The Second Norwegian Polar Expedition in the Fram, 1898-1902, under the leadership of Otto Sverdrup, was primarily aimed at the discovery of the North-West Passage, and the expedition only penetrated southern Nares Strait and Kane Basin. However, the discoveries by the expedition's geologist, Per Schei, had a profound effect on the geological assessment of regions farther north. Thus, Schei's $(1903,1904)$ reports of deformed Mesozoic rocks in western Ellesmere Island influenced both Low (1906) and Willis (1912) who duly assigned the folded Cape Rawson Beds of the Robeson Channel area to the Triassic (see fig. 4).

Sledge contingents of R. E. Peary's expeditions of 1898-1902, 1905-1906 and 1908-1909 
travelled along the outer coast of the Hall Land - Wulff Land region, but apparently few scientific data were recorded.

The region was not visited again until 1917, when the 2nd Thule Expedition, 1916-18, under Knud Rasmussen, travelled across North Greenland, with Lauge Koch as geologist and cartographer. Koch visited the region again in 1921 and 1922 as leader of the Bicentenary Jubilee Expedition, 1920-23. In the course of these expeditions by dog-sledge, he visited the entire outer coast of northern Greenland, including - in the present study region - the western and northern parts of Hall Land, Hendrik $\emptyset$ and the northern and eastern coasts of Nyeboe Land. His study of the strata, so well exposed in the steep fjord and valley walls, resulted in the first systematic geological synthesis of northern Greenland and in five coloured geological maps covering the whole coastal area north of $76^{\circ} \mathrm{N}$ (Koch, 1929b, 1933; Dawes \& Haller, 1979). Koch also published the first stratigraphic and structural details of the Caledonian 'folded mountain chain' of the north coast, and the southern 'great sediment plain' of unfolded Lower Palaeozoic strata to the south (Koch, 1918, 1920, 1923, 1924, 1925, 1929a).

Large numbers of fossils were collected by Koch, mainly from the unfolded strata, and he erected a Cambro-Silurian stratigraphic scheme including some 15 formations. Three of these, the Offley Island, Cape Tyson and Polaris Harbour Formations, were described with type localities in the present study region (Koch, 1929a). Lithostratigraphic frameworks employed by Koch and applicable for the study region are compiled in fig. 5. Poulsen (1927, 1934, 1941, 1943, 1974), Teichert $(1934,1937)$ and Troedsson $(1926,1928)$ described the Lower Palaeozoic fossil collections.

Thirty-five years elapsed before the study region was again visited with the aim of geological study. In 1958-60, during the U.S. Air Force Operation Groundhog, W. E. Davies and D. B. Krinsley of the U.S. Geological Survey carried out helicopter-supported field work throughout northern Greenland, aimed primarily at Quaternary geology, particularly the study of the superficial deposits in connection with the investigation of ice-free aircraft landing sites (Davies, 1961; Davies \& Krinsley, 1961, 1962; Needleman et al., 1961). As regards the present study area, this work resulted in a geological map of Hall Land (scale 1:175 000) and a wealth of Quaternary, glaciological and physiographical observations (Davies, 1963, 1972; Davies et al., 1959). In 1959, during Project Lead Dog, the U.S. Army Transportation Corps reached southern Nyeboe Land by way of the Inland Ice; mainly glaciological data and data relating to physical geology were obtained (Ahnert, 1962, 1963).

To summarise, prior to 1965 the only expeditions to the study region that were specifically directed towards bedrock geological studies were those in which Lauge Koch participated. His reconnaissance between 1916 and 1923 provided the geological maps and stratigraphical framework of western North Greenland until the mid-1960s when Operation Grant Land took place. From 1926, Koch became involved in his lifetime's work in East Greenland, but he kept a keen interest in the geological research of North Greenland. Thus, following seaplane flights in 1933 and 1938 over parts of eastern North Greenland, he managed in 1952 and 1953 from his base in central East Greenland to place parties in the field in Peary Land and Kronprins Christian Land. Later, when vertical aerial photographic coverage of North Greenland became available from the Geodetic Institute, he arranged for a structural analysis of the North Greenland fold belt. The resultant structural map, compiled by John Haller in 1961 at scale 1:250 000, was a first attempt to differentiate between Palaeozoic (pre-Pennsylvanian) and Cenozoic structures of the fold belt (Haller \& Kulp, 1962; Haller, 

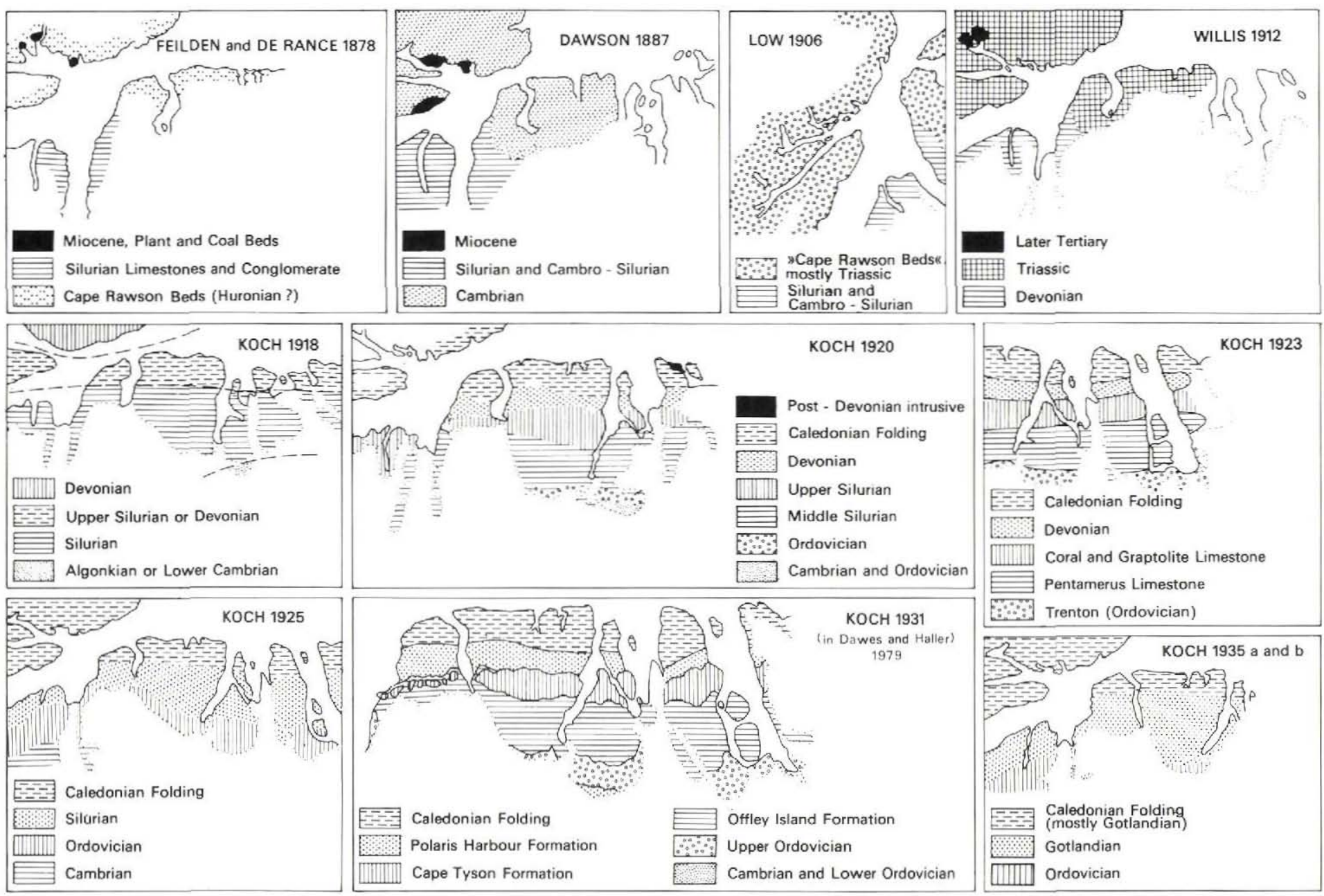


\begin{tabular}{|c|c|c|c|c|c|c|c|}
\hline \multicolumn{4}{|c|}{ 2ND THULE EXPEDITION 1916-1918 } & \multicolumn{4}{|c|}{ BICENTENARY JUBILEE EXPEDITION $1920-1923$} \\
\hline \multicolumn{2}{|l|}{ КОСН 1918} & \multicolumn{2}{|c|}{ КОСН 1920, 1923} & \multicolumn{2}{|c|}{ KOCH 1925} & \multicolumn{2}{|c|}{$\mathrm{KOCH} 1929 \mathrm{a}$} \\
\hline SANDSTONE & \multirow{7}{*}{$\begin{array}{l}\omega \\
- \\
r \\
c \\
D \\
- \\
D \\
z\end{array}$} & $\begin{array}{c}\text { UNFOSSILIFEROUS } \\
\text { SANDSTONE }\end{array}$ & DEVONIAN & SANDSTONE & \multirow{4}{*}{$\begin{array}{l}\text { UPPER } \\
\text { and } \\
\text { MIDDLE } \\
\text { SILURIAN }\end{array}$} & $\begin{array}{c}\text { POLARIS } \\
\text { HARBOUR } \\
\text { FORMATION } \\
\end{array}$ & $\begin{array}{c}\text { UPPER } \\
\text { SILURIAN } \\
\text { (LUDLOW) } \\
\end{array}$ \\
\hline $\begin{array}{l}\text { MONOGRAPTUS } \\
\text { SHALES }\end{array}$ & & $\begin{array}{l}\text { GRAPTOLITE } \\
\text { SHALES } \\
\text { (LIMESTONE) }\end{array}$ & \multirow{2}{*}{$\begin{array}{l}\text { UPPER } \\
\text { SILURIAN }\end{array}$} & $\begin{array}{l}\text { MONOGRAPTUS } \\
\text { SHALES }\end{array}$ & & \multirow{2}{*}{$\begin{array}{c}\text { CAPE } \\
\text { TYSON } \\
\text { FORMATION }\end{array}$} & \multirow{2}{*}{$\begin{array}{c}\text { MIDDLE } \\
\text { SILURIAN } \\
\text { (TARANNON- } \\
\text { WENLOCK) }\end{array}$} \\
\hline $\begin{array}{c}\text { CORAL } \\
\text { LIMESTONE }\end{array}$ & & $\begin{array}{l}\text { CORAL } \\
\text { LIMESTONE }\end{array}$ & & \multirow{2}{*}{$\begin{array}{l}\text { LIMESTONE, SHALE, } \\
\text { CONGLOMERATE, } \\
\text { SANDSTONE } \\
\text { INCL. PENTAMERUS } \\
\text { LIMESTONE }\end{array}$} & & & \\
\hline $\begin{array}{l}\text { RASTRITES } \\
\text { SHALES }\end{array}$ & & \multirow{2}{*}{$\begin{array}{l}\text { PENTAMERUS } \\
\text { LIMESTONE }\end{array}$} & \multirow{2}{*}{$\begin{array}{l}\text { MIDDLE } \\
\text { SILURIAN }\end{array}$} & & & $\begin{array}{l}\text { OFFLEY ISLAND } \\
\text { FORMATION }\end{array}$ & \multirow{2}{*}{$\begin{array}{c}\text { LOWER } \\
\text { SILURIAN } \\
\text { (LLANDOVERY) }\end{array}$} \\
\hline $\begin{array}{l}\text { PENTAMERUS } \\
\text { LIMESTONE }\end{array}$ & & & & $\begin{array}{l}\text { ARETHUSINA * } \\
\text { FORMATION }\end{array}$ & $\begin{array}{l}\text { LOWER } \\
\text { SILURIAN }\end{array}$ & $\begin{array}{l}\text { CAPE SCHUCHERT } \\
\text { FORMATION }\end{array}$ & \\
\hline $\begin{array}{l}\text { ORTHOCERATITE } \\
\text { LIMESTONE }\end{array}$ & & \multirow{2}{*}{$\begin{array}{c}\text { ORTHOCERATITE } \\
\text { LIMESTONE }\end{array}$} & \multirow{2}{*}{ ORDOVICIAN } & \multirow{2}{*}{\multicolumn{2}{|c|}{ ORDOVICIAN }} & $\begin{array}{l}\text { CAPE CALHOUN } \\
\text { FORMATION }\end{array}$ & $\begin{array}{c}\text { UPPER } \\
\text { ORDOVICIAN }\end{array}$ \\
\hline $\begin{array}{l}\text { CORAL } \\
\text { LIMESTONE }\end{array}$ & & & & & & \multicolumn{2}{|c|}{$\begin{array}{l}\text { CAMBRIAN and } \\
\text { LOWER ORDOVICIAN }\end{array}$} \\
\hline $\begin{array}{l}\text { CAMBRIAN or } \\
\text { ALGONKIAN }\end{array}$ & & $\begin{array}{c}\text { RED } \\
\text { SANDSTONE }\end{array}$ & CAMBRIAN? & \multicolumn{2}{|c|}{ CAMBRIAN } & $\begin{array}{c}\text { THULE } \\
\text { FORMATION }\end{array}$ & ALGONKIAN \\
\hline
\end{tabular}

Fig. 4. (Above). Early geological maps of the Hall Land - Wulff Land region. Extracted and redrawn from larger maps with slight modification.

Fig. 5. (Below). Summary of lithostratigraphic schemes pertaining to the Hall Land - Wulff Land region compiled from Lauge Koch's papers and maps. The last column (Koch, 1929a) is compiled with reference to Koch's map of 1931 (see fig. 4). 
1971). Along the outer coast of the Hall Land - Wulff Land region, Haller described a major 'thrust-fold system' (now referred to as the Nyeboe Land fault zone) which he regarded as an eastern expression of the Tertiary Eurekan orogeny of Ellesmere Island.

In 1969, following Operation Grant Land, geologists of Greenarctic Consortium, a Canadian-based commercial organisation, visited western North Greenland and carried out stratigraphical studies from a base camp in southern Wulff Land (personal communication to GGU). The Precambrian crystalline rocks and overlying Lower Palaeozoic cover in the Victoria Fjord arch, and the carbonate shelf rocks containing conspicuous 'patch reefs', were investigated (Stuart-Smith, 1970). No details, or any information from the present study region, have been published, although observations by Greenarctic geologists from adjacent areas to the east and west have been included in a regional geological account of northern Greenland geology (Dawes, 1976).

\section{Field work by GGU}

GGU geologists visited the Hall Land - Wulff Land region in 1977 and on occasions since then. During a study of the Silurian strata in Washington Land in 1977, Hurst (1980) visited Kap Tyson in western Hall Land to examine the Offley Island and Cape Tyson Formations of Koch (1929a). In the course of GGU's 3-year expedition to the Peary Land region, 19781980 , reconnaissance extended as far west as the present study region. The Lower Palaeozoic succession in southern Wulff Land in the Victoria Fjord arch area was briefly investigated in 1978 (Hurst \& Peel, 1979), and air reconnaissance reached as far west as eastern Nyeboe Land. In 1979, one team spent two weeks investigating the Silurian deepwater clastic strata in Wulff Land, Hendrik $\emptyset$, Warming Land, Nyeboe Land and Hall Land (Hurst \& Surlyk, 1982). A second team examined Cambrian and Ordovician platform sequences in southern Wulff Land and Warming Land (Peel, 1980) and the probable early Cambrian carbonates in northern Wulff Land (Peel, 1982, p. 316).

Modern systematic mapping of western North Greenland was initiated in 1984 by GGU's Programme NordGrøn (Dawes, 1984).

Acknowledgements. I am grateful to R. L. Christie, Geological Survey of Canada, for information and help in the compilation of this paper and to Esben Glendal for technical assistance in the preparation of the manuscript. Fig. 2 is published by courtesy of the National Air Photo Library, Ottawa, Canada.

\section{References}

Ahnert, F. 1962: The physical environment of Nyeboe Land, North Greenland. U.S. Army Transportation Corps Final Report, Arctic Proj. Greenland 1959. Virginia, 85 pp.

Ahnert, F. 1963: The terminal disintegration of Steensby Gletscher, North Greenland. J. Glaciol. 4, 537-545.

Allaart, J. H. 1965: The Lower Paleozoic sediments of Hall Land, North Greenland. Unpubl. intern. GGU rep., $11 \mathrm{pp.}$

Allaart, J. H. 1966: Hall Land, Northwest Greenland. Pap. geol. Surv. Can. 66-1, 4 only.

Bendix-Almgreen, S. E. 1976: Palaeovertebrate faunas of Greenland. In Escher, A. \& Watt, W. S. (edit.) Geology of Greenland, 534-573. Copenhagen: Geol. Surv. Greenland.

Bendix-Almgreen, S. E. \& Peel, J. S. 1974: Early Devonian vertebrates from Hall Land, North Greenland. Rapp. Grønlands geol. Unders. 65, 13-16. 
Berry, W. B. N., Boucot, A. J., Dawes, P. R. \& Peel, J. S. 1974: Late Silurian and early Devonian graptolites from North Greenland. Rapp. Grønlands geol. Unders. 65, 11-13.

Bessels, E. 1879: Die amerikanische Nordpol-Expedition. Leipzig: Von Wilhelm Engelmann, 647 pp.

Christie, R. L. 1966: Operation Grant Land. Pap. geol. Surv. Can. 66-1, 3-4.

Christie, R. L. 1967: Operation Grant Land (1966), northern Ellesmere Island. Pap. geol. Surv. Can. 67-1(A), 2-3.

Davies, W. E. 1961: Arctic terrain research for low cost airfield sites; history and results. In Rigsby, G. P. \& Bushnell, V. C. (edit.) Proceedings of the third annual Arctic planning session, November 1960, 8-14. Geophys. Res. Dir. Notes 55, U.S.A.F. Cambridge Res. Center, Bedford.

Davies, W. E. 1963: Glacial geology of northern Greenland. Polarforschung 5(31), 94-103.

Davies, W. E. 1972: Landscape of northern Greenland. Spec. Rep. Cold Reg. Res. Engng Lab. 164, 67 pp.

Davies, W. E. \& Krinsley, D. B. 1961: Evaluation of Arctic ice-free land sites. Kronprins Christian Land and Peary Land, North Greenland 1960. Air Force Surveys in Geophysics 135, 51 pp. U.S.A.F. Cambridge Res. Center, Bedford.

Davies, W. E. \& Krinsley, D. B. 1962: The recent regimen of the ice cap margin in North Greenland. Publ. Ass. Int. Hydrol. Scient. 58, 119-130.

Davies, W. E., Needleman, S. M. \& Klick, D. W. 1959: Report on Operation Groundhog (1958) North Greenland. Investigations of ice-free sites for aircraft landings, Polaris Promontory, North Greenland. U.S.A.F. Cambridge Res. Center, Bedford, 45 pp.

Davis, C. H. 1876: Narrative of the North Polar Expedition U.S. Ship Polaris, Captain Charles Francis Hall commanding. Washington: Gov. Print. Off., 696 pp.

Dawes, P. R. 1966: Lower Palaeozoic geology of the western part of the North Greenland fold belt. Rapp. Grønlands geol. Unders. 11, 11-15.

Dawes, P. R. 1967: Lower Palaeozoic rocks, western part of the North Greenland fold belt. Pap. geol. Surv. Can. 67-1(A), 4-6.

Dawes, P. R. 1971: The North Greenland fold belt and environs. Bull. geol. Soc. Denmark 20, 197-239.

Dawes, P. R. 1976: Precambrian to Tertiary of northern Greenland. In Escher, A. \& Watt, W. S. (edit.) Geology of Greenland, 248-303. Copenhagen: Geol. Surv. Greenland.

Dawes, P. R. 1977: Geological photo-interpretation of Hall Land: part of the regional topographicalgeological mapping of northern Greenland. Rapp. Grønlands geol. Unders. 85, 25-30.

Dawes, P. R. 1979: Computer-supported photogrammetric, geological and topographic mapping of Hall Land, North Greenland. Meddr Inst. Surv. Photogramm. Danm. Tekn. Højsk. 10, 147-170.

Dawes, P. R. 1982: The Nyeboe Land fault zone: a major dislocation on the Greenland coast along northern Nares Strait. In Dawes, P. R. \& Kerr, J. W. (edit.) Nares Strait and the drift of Greenland: a conflict in plate tectonics. Meddr Grønland, Geosci. 8, 177-192.

Dawes, P. R. 1984: Programme NordGrøn (PNG) 1983-1985: regional mapping and geological studies in western and central North Greenland. Rapp. Grønlands geol. Unders. 120, 18-24.

Dawes, P. R. \& Haller, J. 1979: Historical aspects in the geological investigation of northern Greenland. Part 1: New maps and photographs from the 2nd Thule Expedition 1916-1918 and the Bicentenary Jubilee Expedition 1920-1923. Meddr Grønland 200(4), 38 pp.

Dawson, G. M. 1887: Notes to accompany a geological map of the northern portion of the Dominion of Canada, east of the Rocky Mountains. Geol. Nat. Hist. Surv. Can. Ann. Rep. II (R), 56 pp.

Dueholm, K. 1979: Geological and topographical mapping from aerial photographs. Meddr Inst. Surv. Photogramm. Danm. Tekn. Højsk. 10, 9-146.

Etheridge, R. 1878: Palæontology of the coasts of the Arctic lands visited by the late British Expedition under Captain Sir George Nares, R.N., K.C.B., F.R.S. $Q$. Jl geol. Soc. Lond. 34, 568-636.

Feilden, H. W. \& De Rance, C. E. 1878: Geology of the coasts of the Arctic lands visited by the late British Expedition under Captain Sir George Nares, R.N., K.C.B., F.R.S. Q. Jl geol. Soc. Lond. 34, $556-567$. 
Greely, A. W. 1886: Three years of Arctic service. An account of the Lady Franklin Bay Ex 1881-84 and the attainment of the farthest north. London: Richard Bentley \& Son, vol. I: 42 II: $444 \mathrm{pp}$.

Haller, J. 1971: Geology of the East Greenland Caledonides. London: Interscience Publishes Haller, J. \& Kulp, J. L. 1962: Absolute age determinations in East Greenland. Meddr Grønla $77 \mathrm{pp}$.

Hurst, J. M. 1980: Silurian stratigraphy and facies distribution in Washington Land and we Land, North Greenland. Bull. Grønlands geol. Unders. 138, 95 pp.

Hurst, J. M. \& Peel, J. S. 1979: Late Proterozoic (?) to Silurian stratigraphy of southern W North Greenland. Rapp. Grønlands geol. Unders. 91, 37-56.

Hurst, J. M. \& Surlyk, F. 1982: Stratigraphy of the Silurian turbidite sequence of North C Bull. Grønlands geol. Unders. 145, $121 \mathrm{pp}$.

Jackson, D. E. \& Etherington, J. R. 1969: New Silurian cyrtograptid graptolites from nor Canada and northern Greenland. J. Paleont. 43, 1114-1121.

Kerr, J. W. 1967: Nares submarine rift valley and the relative rotation of north Greenland. i Soc. Petrol. Geol. 15, 483-520.

Koch, L. 1918: Oversigt over II Thuleekspeditions videnskabelige Resultater. Naturens Verd. 509.

Koch, L. 1920: Stratigraphy of Northwest Greenland. Meddr dansk geol. Foren. 5(17), 78 p

Koch, L. 1923: Preliminary report upon the geology of Peary Land, Arctic Greenland. Am. J. 189-199.

Koch, L. 1924: De videnskabelige resultater af Jubilæumsekspeditionen Nord om Grønland. F Kartografi og geologi. Geogr. Tidsskr. 27, 208-218.

Koch, L. 1925: The geology of North Greenland. Am. J. Sci. 9, 271-285.

Koch, L. 1929a: Stratigraphy of Greenland. Meddr Grønland 73,2(2), 205-320.

Koch, L. 1929b: The geology of the south coast of Washington Land. Meddr Grønland 73,1(

Koch, L. 1933: The geology of Inglefield Land. Meddr Grønland 73,1(2), 38 pp.

Koch, L. 1935a: Geologie von Grönland. In Krenkel, E. (edit.) Geologie der Erde. Berlin: ' Borntraeger, $159 \mathrm{pp}$.

Koch, L. 1935b: A day in North Greenland. Geogr. Ann., Sven Hedin Bd., 609-620.

Low, A. P. 1906: Report on the Dominion Government Expedition to Hudson Bay and the Arc1 on board the D.G. S. Neptune 1903-1904. Ottawa: Gov. Print. Bureau, 355 pp.

McLean, R. A. 1977: Early Silurian (Late Llandovery) rugose corals from western North G: Bull. Grønlands geol. Unders. 121, 46 pp.

Needleman, S. M., Klick, D. W. \& Molineux, C. E. 1961: Evaluation of an Arctic ice-free lanı results of C-130 aircraft test landings, Polaris Promontory, North Greenland 1958-1959. . Surveys in Geophysics 132, 70 pp. U.S.A.F. Cambridge Res. Center, Bedford.

Norford, B. S. 1967: Biostratigraphic studies, northeast Ellesmere Island and adjacent Greenli geol. Surv. Can. 67-1(A), 12 only.

Norford, B. S. 1972: Silurian stratigraphic sections at Kap Tyson, Offley $\varnothing$ and Kap S northwestern Greenland. Meddr Grønland 195(2), $40 \mathrm{pp}$.

Peel, J. S. 1974: Lower Cambrian fossils from Nyeboe Land, North Greenland fold bel Grønlands geol. Unders. 65, 17 only.

Peel, J. S. 1975: Beatricea from the Ordovician of Hall Land, North Greenland. Rapp. Grønla Unders. 75, 31-34.

Peel, J. S. 1979: Serrodiscus from northern Nyeboe Land, North Greenland. Rapp. Grønla. Unders. 91, 116 only.

Peel, J. S. 1980: Cambrian and Ordovician geology of Warming Land and southern Wulff Lanc North Greenland. Rapp. Gronlands geol. Unders. 101, 55-60. 
Peel, J. S. 1982: The Lower Paleozoic of Greenland. In Embry, A. F. \& Balkwill, H. R. (edit.) Arctic Geology and Geophysics. Mem. Can. Soc. Petrol. Geol. 8, 309-330.

Poulsen, C. 1927: The Cambrian, Ozarkian and Canadian faunas of Northwest Greenland. Meddr Grønland 70,1(2), 233-343.

Poulsen, C. 1934: The Silurian faunas of North Greenland. I. The fauna of the Cape Schuchert Formation. Meddr Grønland 72,2(1), 46 pp.

Poulsen, C. 1941: The Silurian faunas of North Greenland. II. The fauna of the Offley Island Formation. Part I Coelenterata. Meddr Grønland 72,2(2), 28 pp.

Poulsen, C. 1943: The Silurian faunas of North Greenland. II. The fauna of the Offley Island Formation. Part II Brachiopoda. Meddr Grønland 72,2(3), $60 \mathrm{pp.}$

Poulsen, C. 1974: Silurian Pelecypoda, Monoplacophora, and Gastropoda from the reefy facies of the Offley Island Formation of Washington Land and Offley Island (Northwest Greenland). Biol. Skr. Dan. Vid. Selsk. 20(7), 14 pp.

Poulsen, V. 1969: An Atlantic Middle Cambrian fauna from North Greenland. Lethaia 2, 1-14.

Schei, P. 1903: Summary of geological results. In Sverdrup, O. The Second Norwegian Polar Expedition in the 'Fram", 1898-1902. Geogr. J. 22, 56-65.

Schei, P. 1904: Appendix 1. Preliminary account of the geological investigations made during the Second Norwegian Polar Expedition in the Fram. In Sverdrup, O. New Land. Four years in the Arctic regions 2, 455-466. London: Longmans, Green and Co.

Stuart-Smith, J. H. 1970: Hydrocarbon potential of northern Greenland. Bull. Am. Ass. Petrol. Geol. 54(12), 2507 only.

Teichert, C. 1934: Untersuchungen an actinoceroiden Cephalopoden aus Nordgrönland. Meddr Grønland 92(10), $48 \mathrm{pp}$.

Teichert, C. 1937: A new Ordovician fauna from Washington Land, North Greenland. Meddr Grønland 119(1), 65 pp.

Troedsson, G. T. 1926: On the Middle and Upper Ordovician faunas of northern Greenland. I. Cephalopods. Meddr Grønland 71(1), 1-157.

Troedsson, G. T. 1928: On the Middle and Upper Ordovician faunas of northern Greenland. II. Meddr Grønland 72,1(1), $197 \mathrm{pp.}$

Willis, B. 1912: Index to the stratigraphy of North America. Prof. Pap. U.S. geol. Surv. 71, 894 pp.

Wilson, J. T. 1963a: Hypothesis of Earth's behaviour. Nature, Lond. 198, 925-929.

Wilson, J. T. 1963b: Continental drift. Scient. Am. 208(4), 86-100.

Wilson, J. T. 1965: A new class of faults and their bearing on continental drift. Nature Lond. 207, 343347. 